\title{
Особенности петрографического состава обломочной фракции тиллов у д. Варзуга (Терские Кейвы, юг Кольского полуострова)
}

\author{
Носова О.Ю. ${ }^{1}$, Вашков А.А. ${ }^{1}$, Колька В.В. ${ }^{1}$, Корсакова О.П. ${ }^{1}$, Толстобров Д.С. ${ }^{1}$, Костромина Н.А. ${ }^{2}$, \\ Крикунова А.И. ${ }^{2}$ \\ ${ }^{\prime}$ Геологический институт КНЦ РАН, Anamumbl,nosova@geoksc.apatity.ru \\ ${ }^{2}$ Институт наук о Земле СПбГУ
}

Аннотация. Приводятся данные о петрографическом составе крупнообломочной фракции тиллов, участвующих в строении Терских Кейв в районе д. Варзуга и прилегающих моренных равнин. Сравнение составов абляционных тиллов из краевых гряд и базальных тиллов моренной равнины позволило предположить, что образованию флювиогляциальных отложений фрагмента Терских Кейв у д. Варзуга предшествовало проникновение льдов Беломорской лопасти на север, северо-восток во время подвижки отступающего поздневалдайского ледника.

Ключевые слова: Терские Кейвы, тиллы, петрографический состав обломков, направления движения ледника.

\section{Features of petrographical composition of till debris near the Varzuga Village (Terskie Keivy, the south of the Kola Peninsula)}

\author{
Nosova O. Yu. ${ }^{1}$, Vashkov A.A. ${ }^{1}$, Kolka V.V. ${ }^{1}$, Korsakova O.P. ${ }^{1}$, Tolstobrov D.S. ${ }^{1}$, Kostromina N.A. ${ }^{2}$, \\ Krikunova A.I. ${ }^{2}$ \\ ${ }^{1}$ Geological Institute of the Kola Science Centre of RAS, nosova@geoksc.apatity.ru \\ ${ }^{2}$ Institute of Earth Sciences of the St.Petersburg State University
}

\begin{abstract}
There are data on petrographical composition of coarse-clastic fraction of tills studied in sections of the Terskie Keivy near the Varzuga Village and adjacent moraine plains. Comparison of composition of ablation till from the ice-marginal ridges and basal tills of moraine plain allowed to assume that ice of the White Sea Lobe penetrated north-, north-eastwards during readvance of the retreating Late-Weichselian glacier before the fluvioglacial deposits of the Terskie Keivy near the Varzuga Village were formed.
\end{abstract}

Key words: the Terskie Keivy, tills, petrographical composition of debris, ice movement directions.

\section{Введение}

Одними из наиболее спорных в четвертичной геологии Кольского региона являются вопросы механизма и времени формирования ярко выраженных в рельефе ледниковых образований Терских Кейв. Они тянутся параллельно Терскому берегу Белого моря и включают в себя гряды от р. Колвицы до р. Поной (Лаврова, 1960; Стрелков и др., 1976); от р. Варзуги до р. Лумбовки или p. Поной (Hattestrand et al., 2007; Lunkka et al., 2018). Большинство предыдущих интерпретаций генезиса Кейв опиралось преимущественно на их геоморфологические особенности. На сегодняшний день можно выделить несколько основных групп гипотез образования Терских Кейв: 1) Кейвы сформировались в краевой зоне Беломорской лопасти (Апухтин и др., 1967; Евзеров и др., 2000); 2) как краевая зона ледника, покрывавшего внутренние территории Кольского региона (Лаврова, 1960); 3) в краевой зоне между активным или стагнированным льдом Скандинавского ледникового щита, проникшим в центральные части Кольского полуострова, или самостоятельным Понойским ледниковым щитом и Беломорской лопастью Скандинавского щита (Григорьев, 1934; Арманд, 1965; Стрелков и др., 1976; Hattestrand et al., 2007; Lunkka et al., 2018 и др.); 4) образованы льдами Баренцевоморского ледника, проникавшими по горлу Белого моря с севера - северо-востока (Гросвальд, 1996). Стоит отметить, что практически во всех моделях образования Кейв отсутствуют данные об их вещественном составе, хотя этот материал может послужить решающим доводом в доказательство выдвигаемых гипотез и более точно указать на источники поступления обломков, а значит и распространения ледников. Только в работе Стрелкова с соавторами говорится о находках 
терских песчаников севернее их коренных выходов, что позволило говорить о значительном продвижении льдов Беломорской лопасти с юга (Стрелков и др., 1976).

\section{Геологическое строение района работ}

В ходе полевых работ 2018 года были изучены разрезы ледниковых отложений Терских Кейв в районе д. Варзуга (рис. 1). Коренные породы в районе исследований представлены различными гранитоидами Терского, Вороньинского и Стрельнинского комплексов (рис. 1 А). Реже встречаются породы комплекса основания, представленные биотиовыми, амфибол-биотитовыми гнейсами, тоналито-гнейсами, гранодиорито-гнейсами. На севере района работ широко развиты породы западносерговской толщи (риолиты, дацитовые, андезито-дацитовые порфиры и др.) и кислогубской свиты (слюдяные, гранат-слюдяные парагнейсы и сланцы, конгломераты, кварциты). Породы западносерговской толщи прорываются телами габбро-диабазов, габбро-амфиболитов Серговского комплекса. На юге, юго-востоке вдоль побережья Белого моря распространены породы терской свиты - красноцветные песчаники, конгломераты, алевролиты и др. (Геологическая..., 2001).

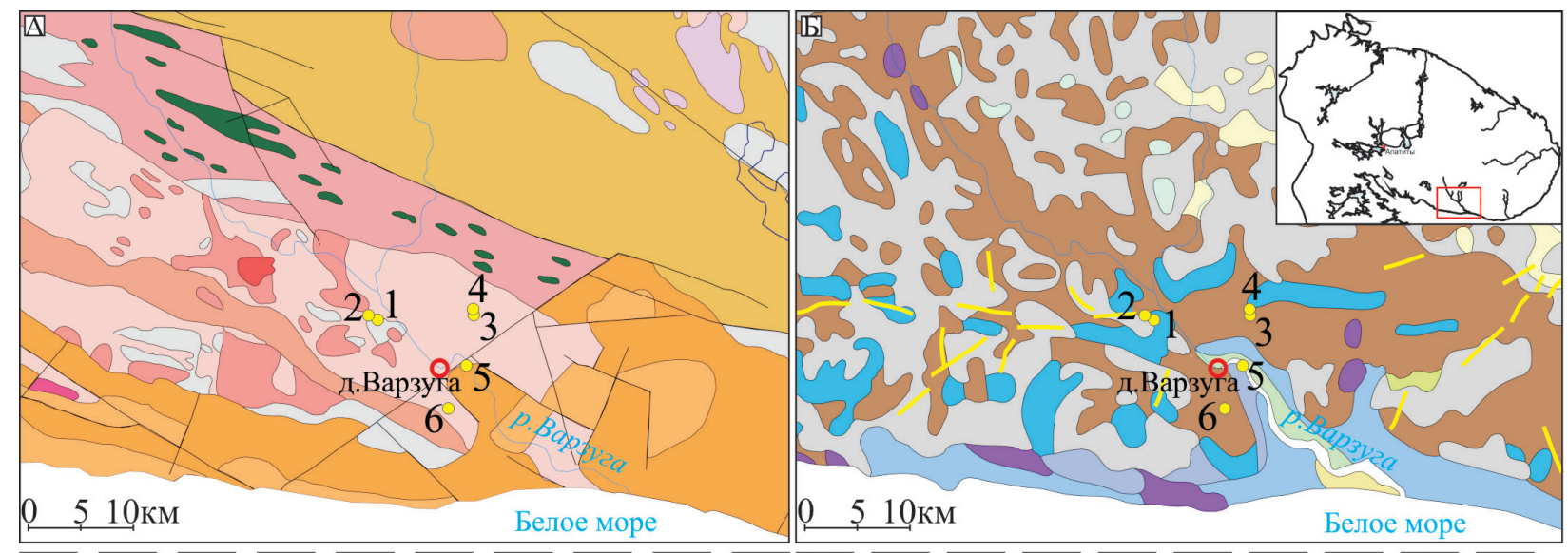

Рис. 1. Геологическая карта дочетвертичных (А) и четвертичных (Б) образований района работ (на основании (Геологическая..., 2001; Государственная..., 2010)).

Дочетвертичные образования (А): 1, 2 - конгломераты, песчаники, алевролиты терской свиты; 3 - лейкограниты Стрельнинского комплекса; 4 - габбро-диабазы, габбро-амфиболиты Серговского комплекса; 5 - риолиты, дациты, туфы, метаосадки западносерговской толщи; 6 - лейкограниты, гранодиориты Вороньинского комплекса; 7 - слюдяные, гранат-слюдяные гнейсы и сланцы кислогубской свиты; 8 - гранодиориты, плагиограниты, тоналиты Терского комплекса; 9 - гнейсы, амфиболиты сергозёрской толщи; 10 - гнейсы биотитовые, амфибол-биотитовые, тоналито-гнейсы, амфиболиты комплекса основания. Четвертичные отложения (Б): 11 - выходы коренных пород; 12 - основная нормально-пластовая морена; 13 - лимногляциальные; 14 - болотные; 15 - современные морские; 16 - морские отложения трансгрессии портландия; 17 - аллювиальноморские; 18 - эоловые; 19 - элювиально-делювиальные; 20 - озы. Цифры на карте - изученные обнажения: 1 Перелой-1; 2 - Перелой-2; 3 - Кицкие Родники-1; 4 - Кицкие Родники-2; 5 - Клетной порог; 6 - Дедкин Ручей.

Fig. 1. Geological map of bedrock (A) and quaternary deposits (Б) of study area (by (Geological..., 2001; State..., 2010)).

Bedrock (A): 1, 2 - conglomerates, sandstones, siltstones of the Terskaya suite; 3 - leucogranites of the Strelna complex; 4 - gabbro-diabases, gabbro-amphibolites of the Serga complex; 5 - riolites, dacites, tuffs, metasediments of the Zapadnosergovskaya unit; 6 - leucogranites, granodiorites of the Voronya complex; 7 - micaceous, garnet-micaceous greisses and schists of the Kislaya Guba suite; 8 - granodiorites, plagiogranites, tonalities of the Tersky complex; 9 - greisses, amphibolites of the Sergozerskaya unit; 10 - biotite, amphibol-biotite gneisses, tonalite-greisses, amphibolites of the Basement complex. Quaternary deposits (Б): 11 - bedrock outcrops; 12 - basal normal-bedded moraine; 13 - limnoglacial; 14 - palustrine; 15 - present marine; 16 - marine deposits of the Portlandia transgression; 17 - alluvial-marine; 18 - eolian; 19 - eluvial-deluvial; 20 - eskers. Numerals on the map - studied outcrops: 1 - Pereloy-1; 2 - Pereloy-2; 3 - Kitskie Rodniki-1; 4 - Kitskie Rodniki-2; 5 - Kletnoy Rapid; 6 - Dedkin Ruchey. 
Изученный участок Терских Кейв представляет собой хорошо выраженные в рельефе цепочки гряд и холмов, осложненные гляциокарстовыми понижениями. Относительная высота гряд 20-30 м. Долина p. Варзуга разделяет Терские Кейвы в районе работ на западный и восточный фрагменты. Согласно различным представлениям Кейвы здесь являются либо флювиогляциальными отложениями типа озов на западе и базальным тиллом на востоке (Государственная..., 2010), либо фрагментарно сложены тиллами и флювиогляциальными отложениями (Лаврова, 1960), либо представлены насыпными и напорно-насыпными моренами (Евзеров и др., 2000), либо являются ледораздельными озами (Четвертичные..., 2003). На севере и юге к Кейвам примыкают моренные равнины с участками развития озёрно-ледниковых отложений и современных болотных образований. Вдоль побережья Белого моря распространены морские отложения, слагающие морские террасы, а также встречаются эоловые образования. (рис. 1 Б).

\section{Методы}

В ходе исследований применялся комплекс геологических, петрографических и геоморфологических методов. Были изучены разрезы ледниковых отложений на поверхности гряд в урочищах Перелой и Кицкие Родники, а также в пределах моренных равнин на севере у подножия гряд и на юге (рис. 1). При изучении разрезов проводилось послойное описание отложений, включающее определение гранулометрического состава, цвета по шкале Munsell, характера ледниковых текстур и др. Петрографический состав крупнообломочной фракции тиллов изучался для валунной (>100 мм), галечной (10-100 мм) и крупногравийной (5-10 мм) фракций. Состав валунной фракции определялся для абляционных тиллов на поверхности гряд в пределах участка $5 \times 5$ м. Галечногравийный материал отбирался из толщ абляционного и базального тиллов из разрезов гряд и прилегающих моренных равнин.

\section{Результаты}

В результате изучения было установлено, что западный и восточный фрагменты Терских Кейв сложены флювиогляциальными образованиями, перекрытыми маломощным абляционным тиллом (рис. 2 А и Б). Типичное строение отложений гряд установлено в разрезе обн. Перелой-1 (N 66² 26'43,6», Е 36² 28'39,8»; рис. 2 А). Сверху вниз отложения представлены:

Слой-1 - песок разнозернистый, преимущественно среднезернистый, коричневато-жёлтого цвета, с гравием, галькой, валунами и значительным содержанием алеврито-глинистых частиц, уплотненный, без видимой слоистости, без закономерности в ориентировке обломков. Мощность 0.2-0.45м.

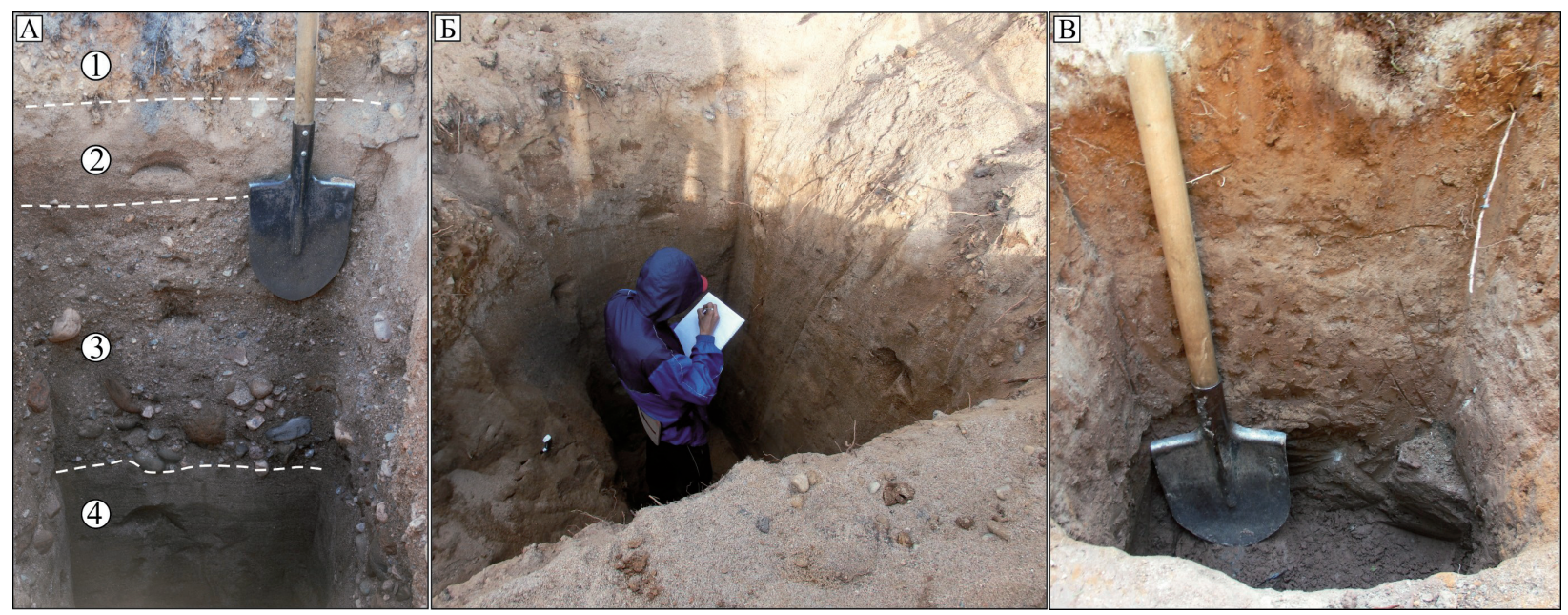

Рис. 2. Фото ледниковых отложений, вскрытых шурфами в точках Перелой-1 (А), Кицкие Родники-1(Б), Кицкие Родники-2 (В). Цифрами в кружках показаны номера слоев согласно тексту.

Fig. 2. Photos of glacial deposits uncovered in pits in the Pereloy-1(A), Kitskie Rodniki-1 (Б), Kitskie Rodniki-2 (B) points. The numerals in circles indicate layer numbers according to the text. 
Слой-2 - песок желтовато-коричневый преимущественно среднезернистый, с небольшим содержанием алеврито-глинистого материала, слоистый. Встречаются отдельные гальки и прослои крупнозернистого песка с гравием. Слоистость падает по азимуту $10^{\circ}$ и углом $11^{\circ}$. Мощность 0.2 м.

Слой-3 - переслаивание песчано-гравийных и песчано-гравийно-галечных смесей с валунами. Материал хорошо промыт, слабо отсортирован. Слоистость падает по азимуту $13^{\circ}$ под углом $13^{\circ}$. Мощность $0.65 \mathrm{~m}$.

Слой-4 - песок среднезернистый серо-жёлтый, сортированный, промытый, с редкими зернами гравия и гальки, слоистый. Слоистость субпараллельная и падает по азимуту $355^{\circ}$ под углом $11^{\circ}$. Мощность вскрытая 0.7 м.

Подобное строение гряды было установлено нами и в восточном фрагменте Кейв - в обн. Кицкие Родники-1. В данных разрезах на петрографический состав был опробован слой абляционного тилла, представленного разнозернистым несортированным песком с гравием, галькой, валунами и алеврито-глинистой составляющей.

Ледниковые отложения, слагающие моренную равнину к югу от Терских Кейв, изучены в обнажении Клетной порог и описаны ранее (Гудина и др., 1973; Корсакова, 2011; Евзеров, 2016). Здесь базальный тилл, залегающий с поверхности и имеющий мощность более 3 м, представлен красносерой супесью с гравием, галькой и валунами. Для него характерна плитчатая текстура, прослои глин и обломки раковин. Аналогичные по цвету и гранулометрическому составу тиллы опробованы южнее в обн. Дедкин Ручей (N 66² ' $44,3 »$, E 36³5'47,5») и у северного подножия восточного фрагмента Терских Кейв (обн. Кицкие Родники-2, N 66²6’32», Е 36²40’52,7») (рис. 1, 2 В).

В результате петрографического анализа обломочного материала установлено (табл. 1):

1) состав абляционных тиллов гряд при доминирующем присутствии местных подстилающих пород (плагиогранитов, гранито-гнейсов, гнейсов) характеризуется также смешением материала, принесённого с северных, северо-западных, западных направлений с материалом южных и юго-западных источников. На северные, северо-западные, западные источники указывает наличие обломков нефелиновых сиенитов Хибинского и Ловозерского массивов, габбро-лабрадорита и габбро-норита с бурым плагиоклазом, возможно принесённых из массивов Фёдорово-Панских тундр (возможные источники габбро-лабрадорита - также массивы Кандалакшский, Колвицкий, Главного хребта), актинолитовых сланцев по базальтам, принадлежащих толщам пояса ИмандраВарзуга и др. На перенос с южных направлений указывает наличие обломков красноцветных песчаников и алевролитов терской свиты.

2) в абляционном тилле западного участка наряду с несколько большим содержанием плагиогранитов и гнейсов (источники - Терский комплекс, комплекс основания, возможно сергозерская толща), отмечается заметное превышение слюдяных гнейсов и сланцев, источником которых являются породы западносерговской толщи или кислогубской свиты, развитые на северо-западе, севере. На восточном участке значительно выше содержания песчаников и алевролитов терской свиты, принесённых с юго-запада, юга.

3) для базальных тиллов моренной равнины характерны высокие или доминирующие содержания терских пород, но также встречаются нефелиновые сиениты Хибинского и Ловозерского массивов и другие породы, принесённые с севера, северо-запада, запада.

4) состав базального тилла моренной равнины, примыкающей с севера к восточному фрагменту Терских Кейв (обн. Кицкие Родники-2), близок к составу базальных тиллов моренной равнины, примыкающей с юга (обн. Дедкин Ручей и Клетной порог) - в сравнении с абляционным тиллом гряды в нём ниже содержания плагиогранитов, гнейсов и др., и больше пород терской свиты, в том числе и зеленовато-серых алевролитов, что характерно для базальных тиллов моренной равнины на юге.

\section{Обсуждение и выводы}

Полученные нами новые данные указывают на движение Беломорской лопасти в районе д. Варзуга с юга, юго-запада на север, северо-восток. Об этом говорит обнаружение насыщенного 
песчаниками базального тилла на севере от восточного фрагмента Терских Кейв. На это также указывает постепенное падение содержания в пробах базальных тиллов обломков зеленовато-серых алевролитов с юга на север (табл. 1). Так как в строении западного и восточного фрагмента гряд не обнаружено базального тилла, перекрывающего отложения, можно утверждать, что изучаемая часть Терских Кейв полностью или частично образовалась при деградации распространившейся на север Беломорской лопасти.-Обнаружение в тиллах вместе с принесённым с юга материалом обломков пород, источники которых расположены на западе, северо-западе и севере, указывает на воздействие льдов, продвигавшихся из центральных частей Кольского региона. Перемещение материала с северных направлений могло происходить во время максимального развития оледенения (поздневалдайского), а продвижение льдов Беломорской лопасти на север, северо-восток связывается нами с подвижкой поздневалдайского отступающего ледника.

Таблица 1. Петрографический состав обломочного материала тиллов Терских Кейв и прилегающих моренных равнин.

Table 1. Petrographical composition of till debris of the Terskie Keivy and adjacent moraine plains.

\begin{tabular}{|c|c|c|c|c|c|c|c|c|c|c|c|c|c|c|}
\hline \multirow{2}{*}{$\begin{array}{c}\text { Группы } \\
\text { пород/минералов }\end{array}$} & \multicolumn{2}{|c|}{$>100 \mathrm{MM}$} & \multicolumn{6}{|c|}{$10-100 \mathrm{Mm}$} & \multicolumn{6}{|c|}{$5-10 \mathrm{MM}$} \\
\hline & $1 a^{*}$ & $3 \mathbf{a}$ & $1 \mathbf{a}$ & $2 a$ & $3 \mathbf{a}$ & $4 \sigma$ & $5 \tilde{0}$ & $6 б$ & $1 \mathbf{a}$ & $2 \mathbf{a}$ & $3 \mathbf{a}$ & 46 & $5 \tilde{5}$ & $6 \tilde{6}$ \\
\hline Песчаники & 5.1 & 65.8 & 9.7 & 10.8 & 27.2 & 39.6 & 59.4 & 57.9 & 7.5 & 10.4 & 24.5 & 31.3 & 53.7 & 47.7 \\
\hline $\begin{array}{l}\text { Алевролиты } \\
\text { (зеленовато-серые) }\end{array}$ & - & - & 0.4 & 0.8 & 0.7 & 6.7 & 10.1 & 19.3 & 0.3 & 1.6 & 1.7 & 7.0 & 12.9 & 21.5 \\
\hline $\begin{array}{l}\text { Плагиограниты, } \\
\text { граниты, гранито-гнейсы, } \\
\text { гнейсы }\end{array}$ & 74.8 & 32.2 & 65.3 & 56.4 & 56.5 & 38.1 & 20.9 & 14.9 & 63.7 & 57.7 & 54.1 & 45.5 & 24.2 & 21.2 \\
\hline Слюдяные гнейсы, сланцы & 3.9 & - & 9.0 & 8.8 & 2.1 & 3.1 & - & - & 7.9 & 9.8 & 0.6 & 2.4 & - & - \\
\hline $\begin{array}{l}\text { Гнейсы с силлиманитом } \\
\text { и/или кордиеритом }\end{array}$ & 0.3 & - & 0.3 & 0.8 & 0.1 & 1.3 & 2.5 & 0.9 & 0.5 & 0.6 & 0.2 & 1.4 & 2.0 & 1.0 \\
\hline \multicolumn{15}{|l|}{ Основные породы, в т. ч.: } \\
\hline Амфиболиты & 10.2 & 0.5 & 4.0 & 10.0 & 3.9 & 4.2 & 1.8 & 1.3 & 3.9 & 5.9 & 3.1 & 4.5 & 1.6 & 2.4 \\
\hline $\begin{array}{l}\text { Метагаббро-милониты/ } \\
\text { основные гранулиты }\end{array}$ & - & - & - & 0.2 & 0.1 & 2.0 & - & 1.8 & 0.1 & 0.5 & - & 0.5 & 0.3 & 0.9 \\
\hline Основные породы разн. & 0.8 & - & 0.5 & 1.1 & 1.0 & 0.2 & 1.1 & 0.4 & 0.1 & 0.4 & 0.5 & 0.2 & 0.8 & 0.8 \\
\hline Перидотиты/оливиниты & 0.1 & - & - & - & - & - & 0.4 & - & - & - & - & 0.1 & 0.1 & 0.1 \\
\hline $\begin{array}{l}\text { Актинолитовые сланцы } \\
\text { (метавулканиты) }\end{array}$ & 3.7 & - & 1.7 & 4.1 & 1.9 & 1.9 & 0.4 & 0.4 & 1.3 & 2.5 & 3.1 & 2.2 & 0.5 & 0.3 \\
\hline Нефелиновые сиениты & 0.5 & 0.5 & 0.7 & 0.4 & - & 0.3 & 0.7 & 1.8 & 0.5 & 0.8 & 0.4 & 0.5 & 0.6 & 0.8 \\
\hline $\begin{array}{l}\text { Жильные щелочные и } \\
\text { лампрофиры }\end{array}$ & 0.1 & - & 0.1 & 0.4 & - & 0.7 & 2.2 & 0.4 & 0.2 & 0.4 & - & 0.2 & 1.0 & 0.1 \\
\hline Фойдолиты & - & - & - & 0.1 & - & 0.2 & - & - & - & - & - & 0.1 & 0.1 & - \\
\hline $\begin{array}{l}\text { Фенитизированные } \\
\text { породы }\end{array}$ & - & - & - & - & 0.1 & - & - & - & 0.1 & - & - & 0.2 & - & 0.2 \\
\hline Полевые шпаты & - & - & 4.0 & 1.8 & 2.8 & 1.1 & 0.7 & - & 7.3 & 5.3 & 5.9 & 1.8 & 1.5 & 2.2 \\
\hline Кварц & 0.5 & 1.0 & 4.5 & 4.2 & 3.6 & 0.8 & - & 0.9 & 6.6 & 4.3 & 5.8 & 2.0 & 0.9 & 0.9 \\
\hline
\end{tabular}

* 1 - Перелой-1; 2 - Перелой-2; 3 - Кицкие Родники- $1 ; 4$ - Кицкие Родники -2; 5 - Клетной порог; 6 - Дедкин Ручей согласно рисунка 1 ; а - абляционный тилл, б - базальный тилл.

Работа выполнена по теме НИР 0226-2019-0054 лаборатории №43 Геологического института КНЦ РАН и в рамках диссертационного исследования. Авторы выражают глубокую благодарность сотрудникам Мурманского филиала ФБУ «ТФГИ по СЗФО» за предоставленный фондовый и каменный материал по геологическому строению дочетвертичных образований в районе работ. 


\section{Литература}

1. Апухтин Н.И., Яковлева С.В. История геологического развития Северо-Запада европейской части СССР в четвертичное время / Геология четвертичных отложений Северо-Запада европейской части СССР. Л. Изд-во: Недра. 1967. С. 318-326.

2. Арманд Н.Н. Краевые образования малоактивного ледникового щита и зона его сочленения со Скандинавским покровом / Краевые образования материкового оледенения. Вильнюс. 1965. С. 45-50.

3. Геологическая карта Кольского региона. Масштаб 1: 1000 000. Гл. ред. Ф. П. Митрофанов. Апатиты. 2001.

4. Государственная геологическая карта Российской Федерации. Масштаб 1: 1000000 (третье поколение). Серия Балтийская. Геологическая карта четвертичных образований. Лист Q-37 (Архангельск). Гл. ред. К.Э. Якобсон. СПб.: Картографическая фабрика ВСЕГЕИ. 2010.

5. Григорьев А.А. Геоморфология Кольского полуострова по новейшим исследованиям // Докл. советских делегатов на Международном Географическом конгрессе в Варшаве. М. 1934. 10 с.

6. Гросвальд М.Г. Последриасовая (< 10 тыс. лет назад) трансгрессия льда Баренцева моря на северовосток Европы // Докл. АН. Т. 350. География. 1996. № 5. С. 687-691.

7. Гудина В.И., Евзеров В.Я. Стратиграфия и фораминиферы верхнего плейстоцена Кольского полуострова. Новосибирск. Изд-во: Наука. 1973. 146 с.

8. Евзеров В.Я. Геология четвертичных отложений Кольского региона. Мурманск. Изд-во: МГТУ. 2016. $210 \mathrm{c}$.

9. Евзеров В.Я., Николаева С.Б. Пояса краевых ледниковых образований Кольского региона // Геоморфология. 2000. № 1. С. 61-73.

10. Корсакова О.П., Семёнова Л.Р., Колька В.В. Средне- и верхнеплейстоценовые осадки в разрезе обнажения Варзуга (юг Кольского полуострова) // Региональня геология и металлогения. 2011. № 48. C. $19-24$.

11. Лаврова М.А. Четвертичная геология Кольского полуострова. М.-Л. Изд-во: Наука. 1960. 233 с.

12. Стрелков С.А., Евзеров В.Я., Кошечкин Б.И.,Рубинраут Г.С., Афанасьев А.П., Лебедева Р.М., Каган Л.Я. История формирования рельефа и рыхлых отложений северо-восточной части Балтийского щита. Л. Изд-во: Наука. 1976. 164 с.

13. Четвертичные отложения Финляндии и Северо-Запада Российской Федерации и их сырьевые ресурсы. Масштаб 1:1000000. Под ред. Й. Ниэмеля, И.М. Экмана, А.Д. Лукашова. 2003.

14. Hattestrand C., Kolka V., Stroeven A.P. The Keiva ice marginal zone on the Kola Peninsula, northwest Russia: a key component for reconstructing the palaeoglaciology of the northeastern Fennoscandian Ice Sheet // Boreas. 2007. V. 36. P. 352-370. DOI: 10.1080/03009480701317488.

15. Lunkka J.P., Kaparulina E., Putkinen N., Saarnisto M. Late Pleistocene palaeoenvironments and the last deglaciation on the Kola Peninsula, Russia // Arktos. 2018. V. 4. P. 1-18. DOI: 10.1007/s41063-018-0053-z. 